\title{
School's Out for COVID-19: 50 Ways BCBA Trainees in Special Education Settings Can Accrue Independent Fieldwork Experience Hours During the Pandemic
}

\author{
Brighid H. Fronapfel ${ }^{1} \cdot$ MaryAnn Demchak ${ }^{2}$ \\ Published online: 26 May 2020 \\ (C) Association for Behavior Analysis International 2020
}

\begin{abstract}
Due to the COVID-19 pandemic and nationwide executive orders closing schools, many trainees completing their supervised independent fieldwork in educational settings lost the ability to accrue hours linked to restricted activities of a therapeutic and instructional nature with students (i.e., clients). Given the impact on trainees of the pandemic restrictions, we present 50 suggestions for trainees in school settings to continue to accrue hours for both restricted and unrestricted activities throughout the course of the COVID-19 pandemic.
\end{abstract}

Keywords Behavior analysis $\cdot$ COVID-19 $\cdot$ Pandemic $\cdot$ supervision

As of April 6, 2020, officials in all 50 states issued orders for school closures through the month of April in response to COVID-19. Such closures are an effort to decrease the spread of COVID-19 through antecedent/preventative measures such as social distancing. At present, many states have school closures through the month of May. However, some states have closed schools for the remainder of the academic year, whereas other states such as North Dakota and New Jersey have closed until further notice. Officials in U.S. territories, such

This manuscript is being published on a highly expedited basis, as part of a series of emergency publications designed to help practitioners of applied behavior analysis take immediate action to adjust to and mitigate the COVID-19 crisis. This article was submitted on April 7, 2020, and received final acceptance on April 11,2020. The journal would like to especially thank Dr. Megan Aclan and Dr. Michael Cameron for their expeditious reviews of the manuscript. The views and strategies suggested by the articles in this series do not represent the positions of the Association for Behavior Analysis International or Springer Nature.

Brighid H. Fronapfel

bfronapfel@unr.edu

MaryAnn Demchak

mad@unr.edu

1 Center for Excellence in Disabilities, University of Nevada, Reno, Mailstop 0285, 1664 N. Virginia Street, Reno, NV 89557, USA

2 Special Education Program, University of Nevada, Reno, Mailstop 0299, 1664 N. Virginia Street, Reno, NV 89557, USA as Puerto Rico, have also issued closures until the middle of April (Peele \& Riser-Kositsky, 2020).

As a result of the nationwide closures, Board Certified Behavior Analyst (BCBA) trainees completing their supervised independent fieldwork in public and private school settings abruptly lost the ability to accrue hours at rates available prior to the pandemic. Because supervision in function and nature is to support trainees in relation to ethical practice, quality of services, professional growth and competence, and work productivity (Kazemi, Rice, \& Adzhyan, 2019), supervisors should continue to perform ethical supervision even under the present conditions and provide opportunities for their trainees to continue to accrue hours for both restricted and unrestricted activities.

Given the limited number of contact hours trainees currently have with their students, those contacts may not even provide the opportunity to engage in behavior-analytic activity. As a result, it is crucial to provide a means of accrual for this specific group of trainees to continue to engage in a comprehensive supervised experience during this unprecedented time. The purpose of this article is to present 50 ways trainees can accrue experience hours that are linked to the Behavior Analyst Certification Board (BACB) 4th and 5th Edition Task Lists (BACB, 2012, 2017).

\section{Overview of Potential Unrestricted Activities}

Given the constraint on student (i.e., client) contact, which eliminates the ability to accrue restricted hours, we emphasize 
BCBA trainees focus on unrestricted activities aimed at building skills related to developing programs and plans for implementation with their students. Unrestricted activities are vital for the preparation of behavior analysts. Table 1 provides a detailed listing of potential activities, Task List linkage, and sample supporting literature for selected activities. Moreover, supervisor observations of and contacts with trainees can occur with many of these activities using various web-based conferencing technologies.

\section{Analysis and Use of Data}

Despite nationwide school closures, trainees may continue to have access to data and support plans that were in place prior to the pandemic. These data provide multiple opportunities for unrestricted hours. First, instructional/acquisition data that were collected prior to school closures can be graphed and analyzed to provide a summary of skill acquisition to be discussed with parents and other school staff. The graphed data can also identify future skill acquisition rates. Reviewing these data may result in data-based modifications to the current plans to facilitate skill acquisition. Trainees can also research the literature regarding data-based decision making and how data inform instructional strategies to be used.

Additionally, trainees can analyze functional behavior assessment (FBA) data that were collected prior to school closures and summarize the data in graphical displays. A review of these data may result in a summary report that identifies conditions under which the behavior was occurring and related recommendations.

Data sheets that trainees modify after analyzing preclosure data, or data sheets that are developed in conjunction with instructional or support plans, can be used to demonstrate interobserver reliability prior to use.

\section{Modifications to Instructional Plans and Behavior Support Plans}

As trainees review data and make data-based decisions, they can complete modifications to plans, as well as develop additional behavior-analytic instruction and related data sheets. Trainees might also review the literature to identify instructional strategies, such as response and stimulus prompts, and to learn how to plan for skill maintenance and generalization and include these methods in instructional plans. This research might aid trainees in developing plans for their learners to promote maintenance and generalization of skills through remote-learning procedures being implemented.

Similarly, analysis of FBA results can then be used to develop or modify behavior support plans. Additionally, research can be conducted on relevant antecedent and consequence strategies, as well as for planning for maintenance and generalization. Just as generalization and maintenance strategies might be used in remote-learning procedures related to instructional plans, they can also be used in remote delivery of services related to behavior support plans.

\section{Development of New Instructional Plans}

Trainees can continue to develop and write new instructional plans for their learners' continued skill acquisition via the virtual-teaching format or for use upon school reopening. Supporting literature for instructional plans can also be researched, read, and applied to instructional plans. This research can focus on any number of behavior-analytic strategies such as response prompting, shaping, chaining, modeling, and video modeling. Some of these strategies may be new to trainees and might require scripting and role-playing so they may demonstrate competency prior to use with their students.

\section{Assessment}

Research of the literature can also be conducted regarding preference assessments for students, and resulting scripts, data sheets, and other corresponding materials can then be prepared. Using these materials, trainees can role-play preference assessments with a supervisor, or in a virtual group supervision session, allowing trainees to demonstrate competence with the task prior to conducting it with a student.

Although it is impossible to conduct direct observations of student behavior in the school setting when schools are closed, trainees might prepare for conducting certain assessments upon the reopening of schools. For example, they may work on indirect assessment methods linked to conducting an FBA to lay the groundwork for conducting antecedent-behaviorconsequence analyses of behavior.

Trainees might also conduct assessments related to the identification of skill strengths and weaknesses for instructional planning. For example, most standardized adaptive behavior instruments (e.g., Vineland Adaptive Behavior Scales) are done via a third-party respondent and do not require direct observation. Trainees can complete such assessments; score, summarize, and identify skill strengths and weaknesses; and use these results to plan for future instruction.

\section{Research and Design of Supports Delivered via Telehealth}

Despite the limitations of applied service delivery via telehealth, there are opportunities for trainees to accrue hours for unrestricted activities. For example, trainees can research literature that demonstrates effective modalities of parent training and use the methods during role-play situations during individual and group supervision sessions. Additionally, trainees can demonstrate competence using parent-training methods during the delivery of telehealth. Likewise, literature 
Table 1. Examples of Unrestricted Trainee Activities Linked to the BACB 4th and 5th Edition Task Lists

Activity Corresponding Corresponding 5th Task Relevant Literature Examples for Selected Activities
4th Task List Item List Item

1. Summarize acquisition data collected prior to school closure (trials to criterion, etc.)

2. Design, plot, and interpret data in various graphical formats.

3. Assess and interpret interobserver A-08 agreement.

4. Review graphed data of learner performance and make data-based decisions for future modifications to instructional plans.

5. Review data collection methods to H- 01 to $\mathrm{H}-05$ determine most appropriate methods for plans.
A-07, A-09, H-04, C-3, C-4, C-5, C-6, C-8, H-05, I-05 C-10, C-11

A-10, A-11 C-10

(1)

$\begin{array}{ll}\begin{array}{ll}\text { A-07, A-09, H-04, } \\ \text { H-05, I-05 }\end{array} & \text { C- } 3, \text { C-4, C-5, C- }-6, \text { C-8 } \\ \text { A-10, A-11 } & \text { C-10 }\end{array}$
Barton, E. E., \& Reichow, B. (2012). Guidelines for graphing data with Microsoft PowerPoint for Office 2007. Journal of Early Intervention, 34, 129-150.

https://doi.org/10.1177/1053815112456601; Dixon, M. R., Jackson, J. W., Small, S. L., Horner-King, M. J., Ker Lik, N. M., Garcia, Y., \& Rosales, R. (2009). Creating single-subject design graphs in Microsoft Excel 2007. Journal of Applied Behavior Analysis, 42, 277-293. https://doi.org/10.1901/jaba.2009.42-277

Fuller, T. C., \& Dubuque, E. M. (2019). Integrating phase change lines and labels into graphs in Microsoft Excel®. Behavior Analysis in Practice, 12, 293-299. https://doi.org/10.1007/s40617-018-0248-6

Ledford, J. R., Lane, J. D., \& Gast, D. L. (2018). Dependent variables, measurement, and reliability. In J. R. Ledford \& D. L. Gast (Eds.), Single case research methodology (3rd ed., chapter 5). New York, NY: Routledge.

Browder, D. M., Demchak, M., Heller, M., \& King, D. (1989). An in vivo evaluation of the use of data-based rules to guide instructional decisions. Journal of the Association for Persons With Severe Handicaps, 14, 234-240. https://doi.org/10. 1177/154079698901400309; Demchak, M., \& Sutter, C. (2019). Teachers' perception of use and actual use of a data-based decision-making. Education and Training in Autism and Developmental Disabilities, 54, 175-185.

Jimenez, B. A., Mims, P. J., \& Browder, D. M. (2012). Data-based decisions guidelines for teachers of students with severe intellectual and developmental disabilities. Education and Training in Autism and Developmental Disabilities, 47, 407-413.

Fiske, K., \& Delmolino, L. (2012). Use of discontinuous methods of data collection in behavioral intervention: Guidelines for practitioners. Behavior Analysis in Practice, 5(2), 77-81. https://doi. org/10.1007/BF03391826

LeBlanc, L. A., Raetz, P. B., Sellers, T. P., \& Carr, J. E. (2016). A proposed model for selecting measurement procedures for the assessment and treatment of problem behavior. Behavior Analysis in Practice, 9, 77-83. https://10.1007/s40617-015-0063-2

$\begin{aligned} & \text { 6. Develop data sheets for behavior } \\ & \text { A-01 to A-14 }\end{aligned}$ C-1 to C-9
(as applicable), I-01

7. Develop data sheets for instructional A-01 to A-14 C-1 to C-9 plans.

8. Develop and write instructional plans for (learner) skill acquisition. I-01

(as applicable),

D-01 to D-21

(as applicable),

E-01 to E-13

(as applicable),

F-01 to F-08

(as applicable),

G-01 to G-08

(as applicable),

J-01 to J-15

(as applicable)

9. Research literature to support instructional plans.

10. Research literature on B-01, B-02

H-2

B-01, B-02 G-4

G-1 to G-22, H-1 to H-5, H-6 to H-9 (if plan is to be implemented via telehealth)
Bambara, L. M., \& Knoster, T. P. (2009). Designing positive behavior support plans (2nd ed.). Washington, DC: AAIDD.

Collins, B. (2012). Systematic instruction for students with moderate and severe disabilities (chapter 2). Baltimore, MD: Brookes.

Collins, B. C., Lo, Y., Park, G., \& Haughney, K. (2018). Response prompting as an ABA-based instructional approach for teaching students with disabilities. TEACHING Exceptional Children, 50, 343-355. https://doi.org/10.1177/0040059918774920 response-prompting procedures to use within instructional plans for skill acquisition (e.g., least-to-most prompts, most-to-least prompts, constant time delay, progressive time delay, graduated guidance).

$\mathrm{B}-\mathrm{O}, \mathrm{B}-\mathrm{02}-\mathrm{G}$


Table 1. (continued)

Activity
Corresponding Corresponding 5th Task Relevant Literature Examples for Selected Activities 4th Task List Item List Item

11. Demonstrate competence in $\quad$ D-03 G-4

implementing response-prompting procedures through role-play with supervisor and other trainees.

12. Teach response-prompting procedures specific to learners to parents and/or other educational staff.

13. Research literature on chaining procedures (i.e., forward chaining, backward chaining, total task) to use within instructional plans for skill acquisition.

14. Demonstrate competence in implementing chaining procedures through role-play with supervisor and other trainees.

15. Teach chaining procedures specific $\mathrm{D}-06, \mathrm{~K}-03$ to learners to parents and/or other educational staff.

16. Research literature on shaping procedures to use within instructional plans for skill acquisition.

17. Demonstrate competence in implementing shaping procedures through role-play with supervisor and other trainees.

18. Teach shaping procedures specific to learners to parents and/or other educational staff.

19. Research literature on imitation, modeling, and video modeling for use in learner instructional plans.

\section{B-01, B-02 G-8}

D-06

B-01, B-02

D-05

D-05, K-03

B-01, B-02

G-5, H-2

Walker, G. (2008). Constant and progressive time delay procedures for teaching children with autism: A literature review. Journal of Autism and Developmental Disorders, 38, 265-271.

Sawyer, M. R., Andzik, N. R., Kranak, M. P., Wilke, C. P., Curiel, E. S. L., Hensley, L. E., \& Neef, N. A. (2017). Improving pre-service teachers' performance skills through behavioral skills training. Behavior Analysis in Practice, 10, 296-300. https://doi.org/10. 1007/s40617-017-0198-4

Jameson, J. M., Walker, R., Utley, K., \& Maughan, R. (2012). A comparison of embedded total task instruction in teaching behavioral chains to massed one-on-one instruction for students with intellectual disabilities: Accessing general education settings and core academic content. Behavior Modification, 36, 320-340. https://doi.org/10.1177/0145445512440574

Slocum, S. K., \& Tiger, J. H. (2011). An assessment of the efficiency of and child preference for forward and backward chaining. Journal of Applied Behavior Analysis, 44, 793-805. https://doi.org/10. 1901/jaba.2011.44-793

Ghaemmaghami, M., Hanley, G. P., Jessel, J., \& Landa, R. (2018). Shaping complex functional communication responses. Journal of Applied Behavior Analysis, 51, 502-520. https://doi.org/10. 1002/jaba.468

Turner, V. R., Ledford, J. R., Lord, A. K., \& Harbin, E. R. (2020). Response shaping to improve food acceptance for children with autism: Effects of small and large food sets. Research in Developmental Disabilities, 98. https://doi.org/10.1016/j.ridd.2020. 103574

Aldi, C., Crigler, A., Kates-McElrath, K., Long, B., Smith, H., Rehak, K., \& Wilkinson, L. (2016). Examining the effects of video modeling and prompts to teach activities of daily living skills. Behavior Analysis in Practice, 9, 384-388. https://doi.org/10. 1007/s40617-016-0127-y

Baker, S. D., Lang, R., \& O'Reilly, M. (2009). Review of video modeling with students with emotional and behavioral disorders. Education and Treatment of Children, 32, 403-420.

Gilson, C. B., \& Carter, E. W. (2018). Video-based instruction to promote employment-related social behaviors for high school students with intellectual disability. Inclusion, 6, 175-193. https://doi.org/10.1352/2326-6988-6.3.175

20. Interpret previously collected

G-01 to G-05, I-05 F-9 functional behavior assessment (FBA) data.

21. Write support plans based on FBA data collected prior to district closures.

D-01 to D-21 (as applicable),

E-01 to E-13

(as applicable), F-01 to F-08 (as applicable), G-01 to G-08 (as applicable), $\mathrm{J}-01$ to $\mathrm{J}-15$

(as applicable)
F-9, G-1 to G-22 (as applicable)

Cipani, E., \& Schock, K. M. (2011). Functional behavioral assessment, diagnosis, and treatment: A complete system for education and mental health settings (2nd ed.). New York, NY: Springer.

Geiger, K. B., Carr, J. E., \& LeBlanc, L. A. (2010). Function-based treatments for escape-maintained problem behavior: A treatment-selection model for practicing behavior analysts. Behavior Analysis in Practice, 3(1), 22-32. https://doi.org/10. 1007/BF03391755

Lipschultz, J., \& Wilder, D. A. (2017). Recent research on the high-probability instructional sequence: A brief review. Journal of Applied Behavior Analysis, 50, 424-428. https://doi.org/10. 1002/jaba.378

Schieltz, K. M., Wacker, D. P., \& Romani, P. W. (2017). Effects of signaled positive reinforcement on problem behavior maintained by negative reinforcement. Journal of Behavioral Education, 26, 137-150. https://doi.org/10.1007/s10864-016-9265-0 
Table 1. (continued)

Activity Corresponding Corresponding 5th Task Relevant Literature Examples for Selected Activities
4th Task List Item List Item

\begin{tabular}{|c|c|c|}
\hline $\begin{array}{l}\text { 22. Plan for training of others (e.g., } \\
\text { parents, paraprofessionals) to } \\
\text { implement behavior support plans } \\
\text { with integrity. }\end{array}$ & K-02, K-03 & $\mathrm{I}-01$ to $\mathrm{I}-03$ \\
\hline $\begin{array}{l}\text { 23. State and plan for unwanted effects } \\
\text { of reinforcement, punishment, and } \\
\text { extinction in relation to acquisition } \\
\text { instructional plans. }\end{array}$ & $\mathrm{C}-01$ to $\mathrm{C}-03$ & H-05 \\
\hline $\begin{array}{l}\text { 24. State and plan for unwanted effects } \\
\text { of reinforcement, punishment, and } \\
\text { extinction in relation to behavior } \\
\text { support plans. }\end{array}$ & C-01 to $\mathrm{C}-03$ & $\mathrm{H}-05$ \\
\hline
\end{tabular}

25. We proposed video samples for the A-01 to A-07 students to use to practice data collection.

26. Research stimulus preference B-01, B-02 $\mathrm{H}-2$ assessments for learners.

\section{Script stimulus preference assessments for learners. \\ 28. Role-play conducting stimulus preference assessments in preparation for use with learners. \\ 29. Train personnel (e.g., aides) to competently conduct stimulus preference assessments.}

30. If accessible, review records and existing data (e.g., educational, medical, historical).

31. Conduct assessments related to identifying skill strengths and weaknesses (e.g., Vineland Adaptive Behavior Scales).

32. Score, interpret, and summarize results of assessments completed to identify skill strengths and weaknesses.

33. Review results of previously completed assessments to determine priority goals.

34. Prepare for conducting FBA upon reopening of schools by completing indirect assessment methods to lay the groundwork for conducting antecedent-behavior-consequence analyses of behavior.

35. Research literature for skill maintenance and generalization for existing learner instructional plans.

I-07, K-03 I-4, I-5

G-01 F-1

I-03, I-04 F-4

H-01 to H-03, I-01 F-7

to I-04
Tiger, J. H., Hanley, G. P., \& Bruzek, J. (2008). Functional communication training: A review and practical guide. Behavior Analysis in Practice, 1, 16-23. https://doi.org/10.1007/BF03391716

Hogan, A., Knez, N., \& Kahng, S. (2015). Evaluating the use of behavioral skills training to improve school staffs' implementation of behavior intervention plans. Journal of Behavioral Education, 24, 242-254. https://doi.org/10.1007/s10864-014-9213-9

Albarran, S. A., \& Sandbank, M. P. (2019). Teaching non-target information to children with disabilities: An examination of instructive feedback literature. Journal of Behavioral Education, 28, 107-140. https://doi.org/10.1007/s10864-018-9301-3

Cooper, J. O., Heron, T. E., \& Heward, W. L. (Eds.). (2020). Applied behavior analysis (3rd ed., chapters 11 and 13). Hoboken, NJ: Pearson.

Smith, R. G., \& Iwata, B. A. (2020). Negative reinforcement. In J. O. Cooper, T. E. Heron, \& W. L. Heward (Eds.), Applied behavior analysis (3rd ed., chapter 12). Hoboken, NJ: Pearson.

C-03 to C-07 LeBlanc, L. A., Raetz, P. B., Sellers, T. P., \& Carr, J. E. (2016). A proposed model for selecting measurement procedures for the assessment and treatment of problem behavior. Behavior Analysis in Practice, 9, 77-83. https://10.1007/s40617-015-0063-2

Tullis, C. A., Cannella-Malone, H. A., Basbigill, A. R., Yeager, A., Fleming, C. V., Payne, D., \& Wu, P.-F. (2011). Review of the choice and preference assessment literature for individuals with severe to profound disabilities. Education and Training in Autism and Developmental Disabilities, 46, 576-595.

Cannella-Malone, H. I., Sabielny, L. M., Jimenez, E. D., \& Miller, M. M. (2013). Pick one! Conducting preference assessments with students with significant disabilities. TEACHING Exceptional Children, 45(6), 16-23. https://doi.org/10. $1177 / 004005991304500602$

Higgins, W. J., Luczynski, K. C., Carroll, R. A., Fisher, W. W., \& Mudford, O. C. (2017). Evaluation of a telehealth training package to remotely train staff to conduct a preference assessment. Journal of Applied Behavior Analysis, 50, 238-251. https://doi.org/10. 1002/jaba. 370

None identified.

I-05 F-2, F-3, F-4

I-05 F-2, F-3, F-4

B-01, B-02 G-21, G-22, H-2
Kritikos, E. P., McLoughlin, J. A., \& Lewis, R. B. (2018). Assessing students with special needs (8th ed., chapter 8). Hoboken, $\mathrm{NJ}$ : Pearson.

Salvia, J., Ysseldyke, J. E., \& Witmer, S. (2017). Assessment in special and inclusive education (13th ed., chapter 13). Boston, MA: Cengage.

Salvia, J., Ysseldyke, J. E., \& Witmer, S. (2017). Assessment in special and inclusive education (13th ed., chapter 4). Boston, MA: Cengage.

Cohen, L. G., \& Spenciner, L. J. (2015). Assessment of children and youth with special needs (5th ed., chapter 7). Hoboken, NJ: Pearson.

OSEP Center on Positive Behavioral Interventions, Sugai, G., Horner, R. H., Dunlap, G., Hieneman, M., Lewis, T. J., . . Turnbull, A. P. (2000). Applying positive behavior support and functional behavioral assessment in schools. Journal of Positive Behavior Interventions, 2, 131-143. https://doi.org/10. $1177 / 109830070000200302$

Stokes, T. F., \& Baer, D. M. (1977). An implicit technology of generalization. Journal of Applied Behavior Analysis, 10, 349-367. https://doi.org/10.1901/jaba.1977.10-349 
Table 1. (continued)

Activity Corresponding Corresponding 5th Task Relevant Literature Examples for Selected Activities
4th Task List Item List Item

$\begin{array}{lll}\begin{array}{l}\text { 36. Develop plans based on research } \\ \text { targeting maintenance and }\end{array} & \text { J-11, J-12 } & \text { G-21, G-22, H-2, H-3 } \\ \text { generalization of skills. } & & \\ \begin{array}{l}\text { 37. Research literature regarding } \\ \text { effective delivery of parent training. }\end{array} & \text { B-01, B-02 } & \text { H-2, H-3 }\end{array}$

38. Develop plans for compassionate delivery of intervention to parents/families (which is especially important during stress of pandemic).

39. Research literature regarding $\quad$ B-01, B-02 telehealth.

40. Conduct parent training via telehealth.

\section{K-01 to K-10 I-1 to I-8}

41. Conduct interobserver agreement checks on data collection sheets that will be utilized during services delivered via telehealth or by caregivers.

42. Conduct treatment integrity checks K-05 for programs delivered via telehealth or by caregivers.

43. Make data-based decisions regarding effectiveness of interventions delivered via telehealth or by caregivers.

44. Research literature related to effective staff training methods.

45. Research literature related to effective performance feedback.

A-09 C-8

H-6

$$
\text { J-15 H-6 to H-9 }
$$

B-01, B-02

B-01, B-02 H-2

46. Conduct virtual staff training (with K-03 paraprofessionals) related to plans for specific learners.

47. Conduct treatment integrity checks K-05 on staff training.

48. Analyze data regarding telehealth $\mathrm{H}-04, \mathrm{H}-05$ delivery of plans.

49. Conduct ethical activities related to B-01, B-02, G-07 practice under present pandemic conditions (i.e., risk/benefit analysis for support plans and possible intervention via one to one or via telehealth). C-10, C-11
Black, M. E., \& Therrien, W. J. (2018). Parent training programs for school-age children with autism: A systematic review. Remedial and Special Education, 39, 243-256. https://doi.org/10. 1177/0741932517730645

Taylor, B. A., LeBlanc, L. A., \& Nosik, M. R. (2018). Compassionate care in behavior analytic treatment: Can outcomes be enhanced by attending to relationships with caregivers? Behavior Analysis Practice, 12, 654-666. https://doi.org/10.1007/s40617-018-00289-3

Tomlinson, S. R. L., Gore, N., \& McGill, P. (2018). Training individuals to implement applied behavior analytic procedures via telehealth: A systematic review of the literature. Journal of Behavioral Education, 27, 172-222. https://doi.org/10. 1007/s10864-018-9292-0

Ferguson, J., Craig, E. A., \& Dounavi, K. (2019). Telehealth as a model for providing behaviour analytic interventions to individuals with autism spectrum disorder: A systematic review. Journal of Autism and Developmental Disorders, 49, 582-616. https://doi.org/10. 1007/s10803-018-3724-5

Ledford, J. R., Lane, J. D., \& Gast, D. L. (2018). Dependent variables, measurement, and reliability. In J. R. Ledford \& D. L. Gast (Eds.), Single case research methodology ( $3 \mathrm{rd}$ ed., chapter 5). New York, NY: Routledge.

Rodriguez, K. (2020). Maintaining treatment integrity in the face of crisis: A treatment selection model for transitioning direct ABA services to telehealth. Behavior Analysis in Practice. Advance online publication. https://doi.org/10.31234/osf.io/phtgv

Allen, K. D., \& Warzak, W. J. (2000). The problem of parental nonadherence in clinical behavior analysis: Effective treatment is not enough. Journal of Applied Behavior Analysis, 33, 373-391. https://doi.org/10.1901/jaba.2000.33-373

Parsons, M. B., Rollyson, J. H., \& Reid, D. H. (2012). Evidence-based staff training: A guide for practitioners. Behavior Analysis in Practice, 5, 2-11. https://doi.org/10.1007/BF03391819

Scheeler, M., Ruhl, K., \& McAfee, J. (2004). Providing performance feedback to teachers: A review. Teacher Education and Special Education, 27, 396-407. https://doi.org/10. $1177 / 088840640402700407$

Tomlinson, S. R. L., Gore, N., \& McGill, P. (2018). Training individuals to implement applied behavior analytic procedures via telehealth: A systematic review of the literature. Journal of Behavioral Education, 27, 172-222. https://doi.org/10. 1007/s10864-018-9292-0

Peterson, L., Homer, A., \& Wonderlich, S. (1982). The integrity of independent variables in behavior analysis. Journal of Applied Behavior Analysis, 15, 477-492. https://doi.org/10.1901/jaba.1982. $15-477$

C-3, C-4, C-5, C-6, C-8, Spriggs, A. D., Lane, J. D., \& Gast, D. L. (2018). Visual representation

E-1, E-2, E-6, E-7, H-2 of data. In J. R. Ledford \& D. L. Gast (Eds.), Single case research methodology (3rd ed., chapter 5). New York, NY: Routledge.

Cox, D. J., Plavnick, J., \& Brodhead, M. T. (2020). A proposed process for risk mitigation during the COVID-19 pandemic. Behavior Analysis in Practice. Advance online publication. https://doi.org/10.31234/osf.io/buetn 
Table 2. Restricted Trainee Activities Linked to the BACB 4th and 5th Edition Task Lists

\begin{tabular}{|c|c|c|c|}
\hline Activity & $\begin{array}{l}\text { Corresponding } \\
\text { 4th Task List } \\
\text { Item }\end{array}$ & $\begin{array}{l}\text { Corresponding } 5 \text { th Task List } \\
\text { Item }\end{array}$ & Relevant Literature Examples \\
\hline $\begin{array}{l}\text { 1. Deliver via telehealth } \\
\text { instructional plans, under } \\
\text { supervision. }\end{array}$ & K & $\begin{array}{c}\text { E-1 to E-6, F-4 to F-7, F-9, } \\
\text { G-1 to G-22 (as applicable), } \\
\text { H-6 to H-9 }\end{array}$ & $\begin{array}{c}\text { Lerman, D. C., O’Brien, M. J., Neely, L., Call, N. A., Tsami, L., } \\
\text { Schieltz, K. M., . . Cooper-Brown, L. (2020). Remote coaching } \\
\text { of caregivers via telehealth: Challenges and potential solutions. } \\
\text { Journal of Behavioral Education. Retrieved from https://rdcu. } \\
\text { be/b3man } \\
\text { Tomlinson, S. R. L., Gore, N., \& McGill, P. (2018). Training } \\
\text { individuals to implement applied behavior analytic procedures } \\
\text { via telehealth: A systematic review of the literature. Journal of } \\
\text { Behavioral Education, 27, 172-222. https://doi.org/10. } \\
\text { 1007/s10864-018-9292-0 }\end{array}$ \\
\hline
\end{tabular}

related to effective staff training methodologies (i.e., behavior skills training) can be researched and the methodologies roleplayed by trainees in various scenarios in order for them to demonstrate competence prior to implementation in a telehealth delivery format. Following competent performance, trainees can utilize the methods to deliver staff training to paraprofessionals and other school staff related to their learners' support plans. Last, trainees can contact the literature and derived ethical activities created by their supervisors related to the practice of behavior analysis under the present pandemic conditions. Additional material can be acquired from various organizations, such as the BACB and the Association of Professional Behavior Analysts, who are providing practice guidance through this unprecedented time.

If telehealth delivery is deemed ethically appropriate, trainees can provide instruction via this format to accrue hours for restricted activities with their learners. The appropriateness of this technology should be gauged in a risk/benefit analysis and implemented only with learners for which the delivery will lead to effective instruction. Table 2 provides a potential restricted activity, Task List linkage, and sample supporting literature.

\section{Consideration of Labor Laws}

When assigning and supervising the unrestricted activities described in this article, give careful consideration to all applicable labor laws. If trainees were working in an hourly paid position to perform these unrestricted activities before the COVID-19 crisis, then labor law may require that they get paid to do these activities now, in which case doing them voluntarily may be unintentionally violating labor law. Therefore, care must be taken to make it clear to everyone involved that the unrestricted activities are not part of any paid job and are purely for training/academic purposes. It is, of course, the responsibility of all BCBAs providing supervision to ensure they and their supervisees comply with applicable laws, and no article - including this one - could possibly give specific guidance that would be relevant to all labor laws in all regions.

\section{Conclusion}

Despite the unexpected impact of the nationwide school closures due to COVID-19, trainees accruing hours in the educational setting can continue their supervisory experience using the 50 tasks described in this article. Although this list is not inclusive of all opportunities for hours, it provides an easy reference for relevant activities for supervisors and trainees linked to both the 4 th and 5th Edition Task Lists (BACB, 2012, 2017) and relevant literature for selected activities that could be used during this unexpected time.

\section{Compliance with Ethical Standards}

Conflict of Interest Neither author has conflicts of interest to report in relation to this writing.

Ethical Approval This writing did not involve the use of human or animal subjects.

Informed Consent Informed consent was not required for this work.

\section{References}

Albarran, S. A., \& Sandbank, M. P. (2019). Teaching non-target information to children with disabilities: An examination of instructive feedback literature. Journal of Behavioral Education, 28, 107-140. https://doi.org/10.1007/s10864-018-9301-3.

Aldi, C., Crigler, A., Kates-McElrath, K., Long, B., Smith, H., Rehak, K., \& Wilkinson, L. (2016). Examining the effects of video modeling and prompts to teach activities of daily living skills. Behavior Analysis in Practice, 9, 384-388. https://doi.org/10.1007/s40617016-0127-y.

Allen, K. D., \& Warzak, W. J. (2000). The problem of parental nonadherence in clinical behavior analysis: Effective treatment is 
not enough. Journal of Applied Behavior Analysis, 33, 373-391. https://doi.org/10.1901/jaba.2000.33-373.

Baker, S. D., Lang, R., \& O'Reilly, M. (2009). Review of video modeling with students with emotional and behavioral disorders. Education and Treatment of Children, 32, 403-420.

Bambara, L. M., \& Knoster, T. P. (2009). Designing positive behavior support plans (2nd ed.). Washington DC: AAIDD.

Barton, E. E., \& Reichow, B. (2012). Guidelines for graphing data with Microsoft PowerPoint for Office 2007. Journal of Early Intervention, 34, 129-150. https://doi.org/10.1177/ 1053815112456601.

Behavior Analyst Certification Board. (2012). BCBA/BCaBA task list (4th ed.). Littleton, CO: Author Retrieved from https://www.bacb. com/bcba-bcaba-task-list/.

Behavior Analyst Certification Board. (2017). BCBA/BCaBA task list (5th ed.). Littleton, CO: Author Retrieved from https://www.bacb. com/bcba-bcaba-task-list-5th-ed/.

Black, M. E., \& Therrien, W. J. (2018). Parent training programs for school-age children with autism: A systematic review. Remedial and Special Education, 39, 243-256. https://doi.org/10.1177/ 0741932517730645.

Browder, D. M., Demchak, M., Heller, M., \& King, D. (1989). An in vivo evaluation of the use of data-based rules to guide instructional decisions. Journal of the Association for Persons With Severe Handicaps, 14, 234-240. https://doi.org/10.1177/ 154079698901400309.

Cannella-Malone, H. I., Sabielny, L. M., Jimenez, E. D., \& Miller, M. M. (2013). Pick one! Conducting preference assessments with students with significant disabilities. TEACHING Exceptional Children, 45(6), 16-23. https://doi.org/10.1177/004005991304500602.

Cengher, M., Budd, A., Farrell, N., \& Fienup, D. M. (2018). A review of prompt-fading procedures: Implications for effective and efficient skill acquisition. Journal of Developmental and Physical Disabilities, 30, 155-173. https://doi.org/10.1007/s10882-0179575-8.

Cipani, E., \& Schock, K. M. (2011). Functional behavioral assessment, diagnosis, and treatment: A complete system for education and mental health settings (2nd ed.). New York, NY: Springer.

Cohen, L. G., \& Spenciner, L. J. (2015). Assessment of children and youth with special needs (5th ed., chapter 7). Hoboken, NJ: Pearson.

Collins, B. (2012). Systematic instruction for students with moderate and severe disabilities (chapter 2). Baltimore, $\mathrm{MD}$ : Brookes.

Collins, B. C., Lo, Y., Park, G., \& Haughney, K. (2018). Response prompting as an ABA-based instructional approach for teaching students with disabilities. TEACHING Exceptional Children, 50, 343-355. https://doi.org/10.1177/0040059918774920.

Cooper, J. O., Heron, T. E., \& Heward, W. L. (2020). Applied behavior analysis (3rd ed., chapters 11 and 13). Hoboken, NJ: Pearson.

Cox, D. J., Plavnick, J., \& Brodhead, M. T. (2020). A proposed process for risk mitigation during the COVID-19 pandemic. Behavior Analysis in Practice. Advance online publication. https://doi.org/ 10.31234/osf.io/buetn

Demchak, M. (1990). Response prompting and fading methods: A review. American Journal on Mental Retardation, 94, 603-615.

Demchak, M., \& Sutter, C. (2019). Teachers' perception of use and actual use of a data-based decision-making. Education and Training in Autism and Developmental Disabilities, 54, 175-185.

Dixon, M. R., Jackson, J. W., Small, S. L., Horner-King, M. J., Ker Lik, N. M., Garcia, Y., \& Rosales, R. (2009). Creating single-subject design graphs in Microsoft Excel 2007. Journal of Applied Behavior Analysis, 42, 277-293. https://doi.org/10.1901/jaba.2009. 42-277.

Ferguson, J., Craig, E. A., \& Dounavi, K. (2019). Telehealth as a model for providing behaviour analytic interventions to individuals with autism spectrum disorder: A systematic review. Journal of Autism and Developmental Disorders, 49, 582-616. https://doi.org/10. 1007/s10803-018-3724-5.

Fiske, K., \& Delmolino, L. (2012). Use of discontinuous methods of data collection in behavioral intervention: Guidelines for practitioners. Behavior Analysis in Practice, 5(2), 77-81. https://doi.org/10. 1007/BF03391826.

Fuller, T. C., \& Dubuque, E. M. (2019). Integrating phase change lines and labels into graphs in Microsoft Excel®. Behavior Analysis in Practice, 12, 293-299. https://doi.org/10.1007/s40617-018-0248-6.

Geiger, K. B., Carr, J. E., \& LeBlanc, L. A. (2010). Function-based treatments for escape-maintained problem behavior: A treatmentselection model for practicing behavior analysts. Behavior Analysis in Practice, 3(1), 22-32. https://doi.org/10.1007/ BF03391755.

Ghaemmaghami, M., Hanley, G. P., Jessel, J., \& Landa, R. (2018). Shaping complex functional communication responses. Journal of Applied Behavior Analysis, 51, 502-520. https://doi.org/10.1002/ jaba.468.

Gilson, C. B., \& Carter, E. W. (2018). Video-based instruction to promote employment-related social behaviors for high school students with intellectual disability. Inclusion, 6, 175-193. https://doi.org/10. 1352/2326-6988-6.3.175.

Higgins, W. J., Luczynski, K. C., Carroll, R. A., Fisher, W. W., \& Mudford, O. C. (2017). Evaluation of a telehealth training package to remotely train staff to conduct a preference assessment. Journal of Applied Behavior Analysis, 50, 238-251. https://doi.org/10.1002/ jaba.370.

Hogan, A., Knez, N., \& Kahng, S. (2015). Evaluating the use of behavioral skills training to improve school staffs' implementation of behavior intervention plans. Journal of Behavioral Education, 24, 242-254. https://doi.org/10.1007/s10864-014-9213-9.

Jameson, J. M., Walker, R., Utley, K., \& Maughan, R. (2012). A comparison of embedded total task instruction in teaching behavioral chains to massed one-on-one instruction for students with intellectual disabilities: Accessing general education settings and core academic content. Behavior Modification, 36, 320-340. https://doi.org/ 10.1177/0145445512440574.

Jimenez, B. A., Mims, P. J., \& Browder, D. M. (2012). Data-based decisions guidelines for teachers of students with severe intellectual and developmental disabilities. Education and Training in Autism and Developmental Disabilities, 47, 407-413.

Kazemi, E., Rice, B., \& Adzhyan, P. (2019). Fieldwork and supervision for behavior analysts: A handbook. New York, NY: Springer.

Kritikos, E. P., McLoughlin, J. A., \& Lewis, R. B. (2018). Assessing students with special needs (8th ed., chapter 8). Hoboken, NJ: Pearson.

LeBlanc, L. A., Raetz, P. B., Sellers, T. P., \& Carr, J. E. (2016). A proposed model for selecting measurement procedures for the assessment and treatment of problem behavior. Behavior Analysis in Practice, 9, 77-83. https://doi.org/10.1007/s40617-015-0063-2.

Ledford, J. R., Lane, J. D., \& Gast, D. L. (2018). Dependent variables, measurement, and reliability. In J. R. Ledford \& D. L. Gast (Eds.), Single case research methodology (3rd ed., chapter 5). New York, NY: Routledge.

Lerman, D. C., O’Brien, M. J., Neely, L., Call, N. A., Tsami, L., Schieltz, K. M., . . Cooper-Brown, L. (2020). Remote coaching of caregivers via telehealth: Challenges and potential solutions. Journal of Behavioral Education. Retrieved from https://rdcu.be/b3man

Lipschultz, J., \& Wilder, D. A. (2017). Recent research on the highprobability instructional sequence: A brief review. Journal of Applied Behavior Analysis, 50, 424-428. https://doi.org/10.1002/ jaba.378.

OSEP Center on Positive Behavioral Interventions, Sugai, G., Horner, R. H., Dunlap, G., Hieneman, M., Lewis, T. J., et al. (2000). Applying positive behavior support and functional behavioral assessment in 
schools. Journal of Positive Behavior Interventions, 2, 131-143. https://doi.org/10.1177/109830070000200302.

Parsons, M. B., Rollyson, J. H., \& Reid, D. H. (2012). Evidence-based staff training: A guide for practitioners. Behavior Analysis in Practice, 5, 2-11. https://doi.org/10.1007/BF03391819.

Peele, H., \& Riser-Kositsky, M. (2020). Map, coronavirus and school closure. Education Week, 1, 41 Retrieved April 6, 2020, from https:/www.edweek.org/ew/section/multimedia/map-coronavirusand-school-closures.html?override=web.

Peterson, L., Homer, A., \& Wonderlich, S. (1982). The integrity of independent variables in behavior analysis. Journal of Applied Behavior Analysis, 15, 477-492. https://doi.org/10.1901/jaba.1982.15-477.

Rodriguez, K. (2020). Maintaining treatment integrity in the face of crisis: A treatment selection model for transitioning direct ABA services to telehealth. Behavior Analysis in Practice. Advance online publication. 10.31234/osf.io/phtgv

Salvia, J., Ysseldyke, J. E., \& Witmer, S. (2017). Assessment in special and inclusive education (13th ed., chapters 4 and 13). Boston, MA: Cengage.

Sawyer, M. R., Andzik, N. R., Kranak, M. P., Wilke, C. P., Curiel, E. S. L., Hensley, L. E., \& Neef, N. A. (2017). Improving pre-service teachers' performance skills through behavioral skills training. Behavior Analysis in Practice, 10, 296-300. https://doi.org/10. 1007/s40617-017-0198-4.

Scheeler, M., Ruhl, K., \& McAfee, J. (2004). Providing performance feedback to teachers: A review. Teacher Education and Special Education, 27, 396-407. https://doi.org/10.1177/ 088840640402700407.

Schieltz, K. M., Wacker, D. P., \& Romani, P. W. (2017). Effects of signaled positive reinforcement on problem behavior maintained by negative reinforcement. Journal of Behavioral Education, 26, 137-150. https://doi.org/10.1007/s10864-016-9265-0.

Slocum, S. K., \& Tiger, J. H. (2011). An assessment of the efficiency of and child preference for forward and backward chaining. Journal of Applied Behavior Analysis, 44, 793-805. https://doi.org/10.1901/ jaba.2011.44-793.
Smith, R. G., \& Iwata, B. A. (2020). Negative reinforcement. In J. O. Cooper, T. E. Heron, \& W. L. Heward (Eds.), Applied behavior analysis (3rd ed., chapter 12). Hoboken, NJ: Pearson.

Spriggs, A. D., Lane, J. D., \& Gast, D. L. (2018). Visual representation of data. In J. R. Ledford \& D. L. Gast (Eds.), Single case research methodology (3rd ed., chapter 5). New York, NY: Routledge.

Stokes, T. F., \& Baer, D. M. (1977). An implicit technology of generalization. Journal of Applied Behavior Analysis, 10, 349-367. https:// doi.org/10.1901/jaba.1977.10-349.

Taylor, B. A., LeBlanc, L. A., \& Nosik, M. R. (2018). Compassionate care in behavior analytic treatment: Can outcomes be enhanced by attending to relationships with caregivers? Behavior Analysis Practice, 12, 654-666. https://doi.org/10.1007/s40617-018-002893

Tiger, J. H., Hanley, G. P., \& Bruzek, J. (2008). Functional communication training: A review and practical guide. Behavior Analysis in Practice, 1, 16-23. https://doi.org/10.1007/BF03391716.

Tomlinson, S. R. L., Gore, N., \& McGill, P. (2018). Training individuals to implement applied behavior analytic procedures via telehealth: A systematic review of the literature. Journal of Behavioral Education, 27, 172-222. https://doi.org/10.1007/s10864-018-9292-0.

Tullis, C. A., Cannella-Malone, H. A., Basbigill, A. R., Yeager, A., Fleming, C. V., Payne, D., \& Wu, P.-F. (2011). Review of the choice and preference assessment literature for individuals with severe to profound disabilities. Education and Training in Autism and Developmental Disabilities, 46, 576-595.

Turner, V. R., Ledford, J. R., Lord, A. K., \& Harbin, E. R. (2020). Response shaping to improve food acceptance for children with autism: Effects of small and large food sets. Research in Developmental Disabilities, 98. https://doi.org/10.1016/j.ridd.2020. 103574.

Walker, G. (2008). Constant and progressive time delay procedures for teaching children with autism: A literature review. Journal of Autism and Developmental Disorders, 38, 265-271.

Publisher's Note Springer Nature remains neutral with regard to jurisdictional claims in published maps and institutional affiliations. 